\title{
High Connectivity of the White Seabream (Diplodus sargus, L. 1758) in the Aegean Sea, Eastern Mediterranean Basin
}

\author{
Athanasios Exadactylos ${ }^{1, *(1)}$, Dimitrios Vafidis ${ }^{1}$, Costas $S$. Tsigenopoulos ${ }^{2}(\mathbb{D}$ and \\ Georgios A. Gkafas ${ }^{1}$ ** \\ 1 Department of Ichthyology and Aquatic Environment, School of Agriculture Sciences, \\ University of Thessaly, 38446 Volos, Greece; dvafidis@uth.gr \\ 2 Institute of Marine Biology, Biotechnology and Aquaculture, Hellenic Centre for Marine Research, \\ 71003 Heraklion, Greece; tsigeno@hcmr.gr \\ * Correspondence: exadact@uth.gr (A.E.); gkafas@uth.gr (G.A.G.); Tel.: +30-242-109-3073 (A.E.); \\ $+30-242-109-3145$ (G.A.G.)
}

Received: 7 October 2019; Accepted: 14 November 2019; Published: 15 November 2019

Simple Summary: Population dynamics is important for the estimation of the ecology and conservation status of the species in question. Levels of genetic structure, connectivity, gene flow and genetic diversity often differ in the marine environment due to the apparent lack of barriers. In the present study, the population structure of a highly economical species, the white seabream, was evaluated using short tandem repeats. Results suggest high connectivity in the Aegean sea, eastern Mediterranean sea, indicating the possibility of a probable movement of adult migrants or strong passive drift at sea in the early life stages of the species. However, it is clear that different species within the Sparidae family favor altered strategies, as discussed in the study, and information of this kind needs to be evaluated by ecologists with respect to potential different conservation and resources-management policies for the eastern Mediterranean basin.

\begin{abstract}
Population dynamics in the marine realm can shape species' spatial structure and genetic variability between given geographical areas. Connectivity is an important factor of species' population structure. In this study, we examined the genetic diversity and structure of white seabream (Diplodus sargus, L. 1758) in the eastern Mediterranean basin, using a panel of four microsatellite markers. Recorded low $F_{S T}$ values within the study area indicate little evidence of genetic differentiation among populations. Results suggest high gene flow which may imply near-panmixia between populations, indicating the possibility of a probable movement of adult migrants, or strong passive drift at sea in early life stages of the species. To this extent, bibliographically speaking, different species within the Sparidae family favor altered population dynamics patterns with respect to local populations and genetic divergence, in the context of the molecular marker used.
\end{abstract}

Keywords: connectivity; Mediterranean; population structure; microsatellites

\section{Introduction}

Population structure at sea is cryptic due to the absence of physical barriers. However, with respect to different marine taxa, population structure can differ, e.g., [1,2] depending on life history traits, and it can be used to better understand population connectivity and population dynamics [3]. The white seabream (Diplodus sargus, L. 1758) populations favor a typical homogeneous mixture of individuals, thus suggesting low genetic differentiation and high levels of connectivity [4-6]. However, sister species within the Sparidae family seem to follow a differential strategy; such is the case of saddled seabream 
(Oblada melanura, L. 1758), where statistically significant genetic differentiation among populations in the Aegean Sea illustrates a potential small-scale population structure [7]. On the other hand, connectivity in the marine environment is a rather common situation due to potential complex migratory patterns and admixture; under the population genetic framework one could evaluate the scale of dispersal of marine taxa [8]. Indeed, documented species with long-lived larval stages favor relatively low population structure and high gene flow and theoretically can enable connectivity over large distances due to life-history traits and environmental pressures [9]. Also expected is that long-lived larvae under passive drift form panmictic stocks [10] and dispersal is likely to occur mainly during the pelagic larval phase before settlement [11]. However, massive larvae dispersal by hydrographical processes is very unlikely to occur [12]. Barcelloni et al. [13] suggest that ecological/historical factors might have caused discrepancy in the geographical distribution of genetic variation among otherwise biologically similar species.

Inferring demographic connectivity from molecular markers has gained awareness, especially for conservation and fisheries management purposes [14]. Fisheries management modeling can provide a holistic view of stocks' dynamics giving a better understanding on structure and connectivity [15]. Ecological management modeling can play a vital role in improving complex population structure within certain areas, shedding light on stock identification [16].

These two features, a focus on larval survivors and an ability to examine long-term mean population connectivities, are critical contributions that genetic studies can make to marine population dynamics. However, genetic surveys of marine populations also face a number of severe challenges that have limited the impact of these approaches on marine ecology, coastal management, or fisheries preservation. The challenges inherent in such accurate genetic determinations have slowed the use of genetic data to estimate real-time population connectivities and have frustrated the use of genetics in many conservation and fisheries contexts [14].

Neutral markers, such as microsatellites, have been used exclusively to identify the geographic structure of subpopulations and estimate the genetic connectivity. In this study, four microsatellites were used to assess the population structure of the white seabream. The white seabream belongs to the Sparidae family and it is found from the Atlantic to the Indian Ocean, in the Mediterranean Sea and the Persian Gulf [17]. Pelagic larvae behavioral pattern and juvenile migration movement towards deeper habitats have been illustrated so far [18], in order to discuss the species recruitment strategy into adult populations. Here, we addressed the level of genetic diversity and discussed the genetic structure strategy of the species in question in the eastern Mediterranean basin.

\section{Material and Methods}

\subsection{Sampling Design and Molecular Techniques}

Samples from local fish markets were collected from six different geographical areas in the Aegean Sea, as shown in Figure 1. The total sample size was 166 mature specimens. An adequate proportion of muscle tissues were stored in $20 \%$ DMSO NaCl 5M. DNA was extracted following the standard phenol/chloroform extraction protocol [19]. DNA was preserved in $10 \mathrm{mM}$ TE (Tris-HCl, EDTA) and stored in $-20^{\circ} \mathrm{C}$. A total panel of four DNA microsatellite markers $[20,21]$ were tested and optimized for the genetic analyses (Table 1) due to their high variability (see review in $[20,21]$ ). A multiplex PCR Kit (Qiagen) with a hot start Taq polymerase was used for the DNA amplifications. The PCR cycling profile was: $95^{\circ} \mathrm{C}$ for $15 \mathrm{~min} ; 30$ cycles of $95^{\circ} \mathrm{C}$ for $1 \mathrm{~min}$, annealing temperature (Table 1) for $30 \mathrm{~s}$ and $72{ }^{\circ} \mathrm{C}$ for $30 \mathrm{~s} ; 72{ }^{\circ} \mathrm{C}$ for $15 \mathrm{~min}$. PCR products were verified by agarose gel electrophoresis. Amplified DNA products were screened on an ABI 3730 DNA Analyzer (Applied Biosystems). Each specimen's alleles were scored by the STRand software v.2.0 [22] and the $10 \%$ of genotypes were re-assessed for error checking. 


\subsection{Statistics}

All loci were tested for the presence of null alleles, or allelic dropout using the software Micro-Checker v. 2.2.3 [23], where a Monte Carlo simulation method was used to generate expected homozygote and heterozygote allele size difference frequencies. Exact tests for Hardy-Weinberg equilibrium, linkage disequilibrium (using Fisher's Exact Test), expected heterozygosity $\left(H_{E X P}\right)$ and observed heterozygosity ( $\left.H_{O B S}\right)$ were carried out using the software Genepop v. 3.4 [24]. Fixation indexes $F_{S T}$ and $F_{I S}$ (using the formulations described by [25]), number of alleles per locus were calculated using the FSTAT v. 2.9.3.2 software [26]. Population structure was further assessed using the software LEA as implemented in R platform [27] to test for presence of distinct genetic clusters and subpopulations. The admixture model-based STRUCTURE simulations were conducted at varying levels of possible population numbers. To test the convergence of the priors and the appropriateness of the chosen burn-in length and simulation length, three independent repeats were run for each value of $K(1 \leq K \leq 10)$. Burn-in length and length of simulation were set at 500,000 and 1,000,000 repetitions, respectively. The cross-entropy criterion was used for choosing the number of genetic clusters. This criterion is based on the prediction of a fraction of masked genotypes (matrix completion), and on the cross-validation approach. Smaller values of the cross-entropy criterion mean better runs. Significance level was adjusted according to Bonferroni correction [28].

\section{Results}

Among the four loci screened (a subset of the genetic data can be found in the Supplementary Materials Table S1), none of them showed evidence of null alleles. The observed heterozygosity values were high enough $(0.580 \pm 0.156$ s.d. to $0.917 \pm 0.096$ s.d. $)$, but within the range observed in the bibliography for fish species. Nevertheless, no statistical departure from the Hardy-Weinberg law was detected $\left(P_{99}\right.$ criterion), as shown in Table 1 . The mean genetic heterogeneity value $\left(F_{S T}\right)$ was quite low $(0.008 \pm 0.010$ s.d. $)$ indicating little evidence of genetic differentiation among populations (Table 2). The number of genetic clusters through LEA program was based on the cross-entropy criterion (Figure 2), revealing the presence of two subpopulations, which also indicates high gene flow and admixture of individuals among the studied geographical area (Figure 1).

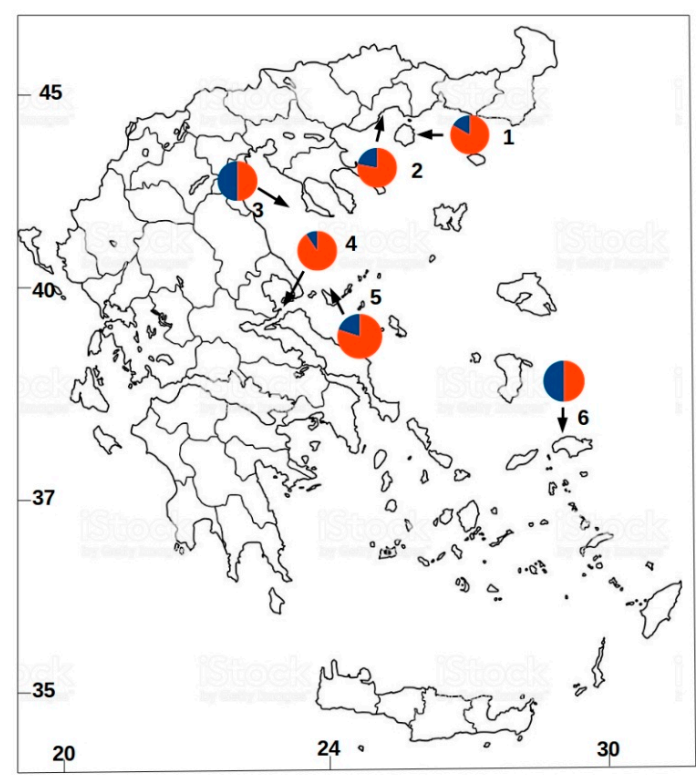

Figure 1. Sampling locations in the Aegean Sea and structure pies with locprior $K=2$ (different colors represent the two different genetic clusters). Numbers indicate the sampled area of individuals. 1: Thasos (THA) — 30 specimens; 2: Kavala (KAV)—24 specimens; 3: Chalkidiki (CHA)—28 specimens; 4: Trikeri (TRI)—28 specimens; 5: Sporades (SPO)—26 specimens; 6: Samos (SAM)—30 specimens. 


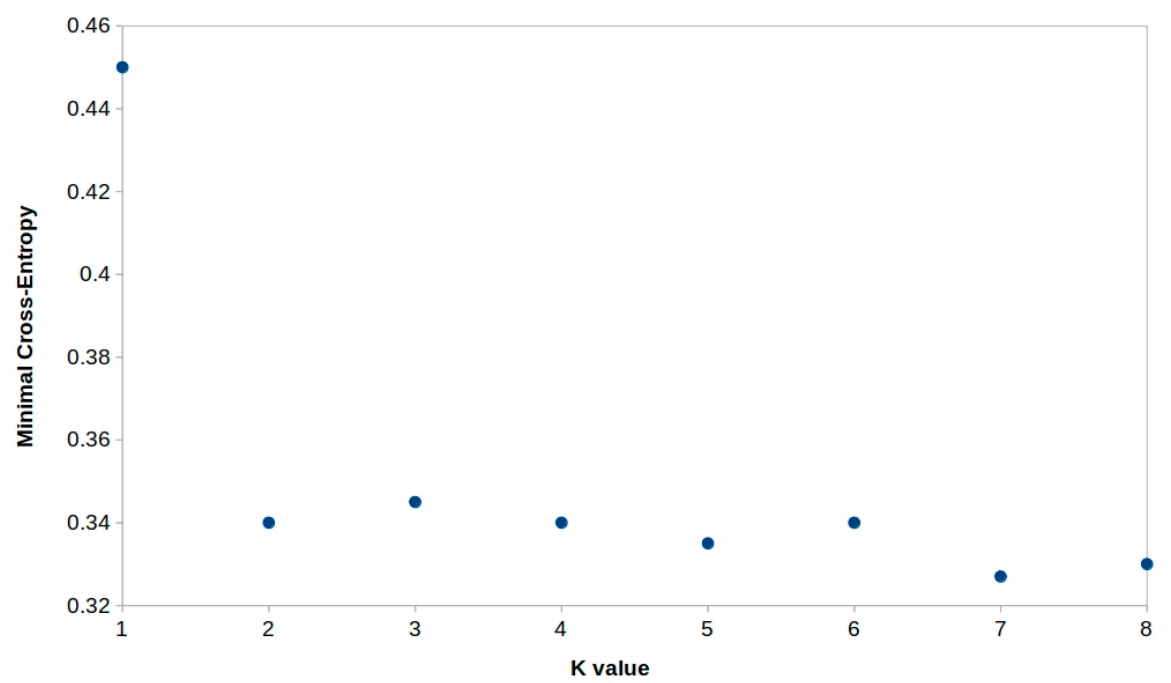

Figure 2. Cross-entropy plot for the number of cluster $K=1-8$. The retained value of $K$ is $K=2$.

Table 1. The panel of the four microsatellite DNA markers with annealing temperature in parentheses. NoA: number of alleles; $H_{E X P}$ : expected heterozygosity; $H_{O B S}$ : observed heterozygosity.

\begin{tabular}{|c|c|c|c|c|c|c|c|}
\hline $\begin{array}{l}\text { Microsatellite } \\
\text { DNA Markers }\end{array}$ & $\begin{array}{l}\text { Genetic } \\
\text { Indices }\end{array}$ & TRI & SPO & THA & KAV & CHA & SAM \\
\hline \multirow{3}{*}{$\operatorname{Pma} 1\left(57^{\circ} \mathrm{C}\right)$} & NoA & 10 & 15 & 14 & 13 & 19 & 7 \\
\hline & $H_{E X P}$ & 0.970 & 0.974 & 0.949 & 0.921 & 0.957 & 0.909 \\
\hline & $H_{O B S}$ & 1.000 & 0.900 & 0.667 & 0.714 & 0.833 & 0.833 \\
\hline \multirow{3}{*}{$\operatorname{Pma2}\left(57^{\circ} \mathrm{C}\right)$} & NoA & 9 & 11 & 10 & 13 & 17 & 9 \\
\hline & $H_{E X P}$ & 0.955 & 0.895 & 0.866 & 0.812 & 0.924 & 0.955 \\
\hline & $H_{O B S}$ & 1.000 & 0.900 & 0.917 & 0.714 & 0.833 & 1.000 \\
\hline \multirow{3}{*}{$\operatorname{SAI10}\left(58^{\circ} \mathrm{C}\right)$} & NoA & 9 & 11 & 11 & 12 & 18 & 11 \\
\hline & $H_{E X P}$ & 0.955 & 0.932 & 0.917 & 0.910 & 0.952 & 0.985 \\
\hline & $H_{O B S}$ & 0.667 & 0.700 & 0.500 & 0.428 & 0.647 & 1.000 \\
\hline \multirow{3}{*}{ SAI12 $\left(59^{\circ} \mathrm{C}\right)$} & NoA & 8 & 10 & 12 & 14 & 16 & 9 \\
\hline & $H_{E X P}$ & 0.939 & 0.889 & 0.942 & 0.951 & 0.928 & 0.955 \\
\hline & $H_{O B S}$ & 0.500 & 0.500 & 0.583 & 0.462 & 0.667 & 0.833 \\
\hline
\end{tabular}

Table 2. $F_{S T}$ pairwise values of the white seabream populations within the Aegean Sea.

\begin{tabular}{ccccccc}
\hline Populations & TRI & SPO & THA & KAV & CHA & SAM \\
\hline SPO & -0.0074 & 0 & & & & \\
THA & -0.0111 & -0.0006 & 0 & & & \\
KAV & -0.0148 & 0.0039 & 0.0096 & 0 & & \\
CHA & -0.0057 & 0.0192 & 0.0053 & 0.0151 & 0 & \\
SAM & 0.0047 & 0.0105 & 0.0213 & 0.0169 & 0.0060 & 0 \\
\hline
\end{tabular}

\section{Discussion}

The present study indicated a significant connectivity pattern for contiguous populations of white seabream throughout the study area. The structural analysis result was that of a two cluster assignment of populations which significantly correspond to high mixing of all individuals. Published studies show similar a genetic homogeneity strategy for the species in question within the Mediterranean Sea, e.g., see $[4,5]$. The Aegean Sea exhibits genetic continuity of white seabream populations, which may 
be influenced by the ocean currents, in the context of the relatively long planktonic larval phases that suggest relatively high connectivity [29] and possible differential recruitment process [6].

On the other hand, according to previously reported studies of other benthopelagic Sparidae species [7], north and central Aegean populations seem to force species to form and exhibit complex spatial patterns with respect to their benthic and geographic abundance [30]. This might be explained by the dynamic status of the eastern Mediterranean Sea with respect to the physiographic and hydrodynamic complexity, such as the prevailing unique oceanographic features and different water masses compared to the western Mediterranean basin; see review in [31]. Previous studies within the Aegean Sea show absence of interpopulation genetic structure [32], suggesting the existence of single stocks within certain areas within the eastern Mediterranean basin [33]. This might be due to large effective population sizes that limit genetic drift and life history characteristics that favor dispersal in continuous dynamic oceanic environments (see review in [34]).

Taking into consideration the results presented here, we suggest a considerably high connectivity for this Sparidae species in the eastern Mediterranean Sea. This may be an effect of the mixing of adult individuals in apparently similar geographic areas, which may also contribute to the low differentiation and high connectivity between samples within the Aegean Sea. Different strategies within Sparidae family, with respect to different larvae phases, seem to shape differential genetic composition and population dynamics, e.g., see [8]. Moreover, oceanographic and environmental features affect larval behavior, forcing structuring mechanisms to dispersal, retention or larvae settlement [35]. This larval drift may shape population differentiation and is considered of high importance of connectivity [36]. Seasonal shifts in habitat uses, life cycle, and, most important, spawning fidelity are a common strategy of many species [37]. Also, species' phenotypic plasticity and diet behavior influence different feeding strategies, resulting altered ecological behaviors [38]. Such an ecological alteration is often characterized by strong seasonality through annual temporal patterns of biological processes [39]. It is then suggested that species-specific temporal patterns were found demonstrating a clear annual temporal niche partitioning within the Sparidae family [40].

However, one should take into account that sample sizes and the panel of microsatellite markers are just on the verge of the scientific protocol adequacy. Species' geographical dispersal might be closely linked to oceanographic features and specific ecological habitats and can provide an efficient tool for distribution and abundance identification of all Sparidae species in a conservation management plan for the eastern Mediterranean basin. Populations of the same species may vary in experiencing different recruitment success or survival rates under different environmental conditions [16,41]. The complex nature of a population structure may mislead the spatially sampled stock that is used for management purposes [42]. One such example is the collapse of Atlantic cod, due to the ineffective recognition to acknowledge stock boundaries, complex structure, and spawning areas in the north Atlantic [43-45]. Thus, a better understanding of spatial structure and connectivity may play a key role with respect to fisheries management such as recruitment, overfishing, conservation, and environmental interactions [46].

These findings reveal complex population dynamics patterns within the Sparidae family and therefore have important implications on differential policies for the effective conservation and management for each species within the family.

Supplementary Materials: The following are available online at http://www.mdpi.com/2076-2615/9/11/979/s1, Table S1: Subset of the microsatellite genetic data.

Author Contributions: Conceptualization, A.E. and G.A.G.; methodology, A.E. and G.A.G.; software, A.E., G.A.G. and C.S.T.; validation, A.E. and G.A.G.; resources, A.E. and D.V.; data curation, D.V.; writing-original draft preparation, A.E., D.V. and G.A.G.; writing-review and editing, A.E., D.V., C.T. and G.A.G.

Funding: This research received no external funding.

Conflicts of Interest: The authors declare no conflict of interest. 


\section{References}

1. Moura, A.E.; Natoli, A.; Rogan, E.; Hoelzel, A.R. Atypical panmixia in a European dolphin species (Delphinus delphis): Implications for the evolution of diversity across oceanic boundaries. J. Evol. Biol. 2013, 26, 63-75. [CrossRef] [PubMed]

2. Gkafas, G.A.; Exadactylos, A.; Rogan, E.; Raga, J.A.; Reid, R.; Hoelzel, A.R. Biogeography and temporal progression during the evolution of striped dolphin population structure in European waters. J. Biogeogr. 2017, 44, 2681-2691. [CrossRef]

3. Bailleul, D.; Mackenzie, A.; Sacchi, O.; Poisson, F.; Bierne, N.; Arnaud-Haond, S. Large-scale genetic panmixia in the blue shark (Prionace glauca): A single worldwide population or a genetic lag-time effect of the "grey zone" of differentiation? Evol. Appl. 2018, 11, 614-630. [CrossRef] [PubMed]

4. Lenfant, P. Demographic and genetic structures of white seabream populations (Diplodus sargus, Linnaeus, 1758) inside and outside a Mediterranean marine reserve. Comptes Rendus Biol. 2003, 325, 239-252. [CrossRef]

5. González-Wangüemert, M.; Pérez-Ruzafa, A.; Cánovas, F.; García-Charton, J.A.; Marcos, C. Temporal genetic variation in populations of Diplodus sargus from the SW Mediterranean Sea. Mar. Ecol. Prog. Ser. 2006, 334, 237-244. [CrossRef]

6. Hernández-García, R.; Muñoz, I.; López-Capel, A.; Marcos, C.; Pérez-Ruzafa, Á. The influence of environmental variability of a coastal lagoon ecosystem on genetic diversity and structure of white seabream [Diplodus sargus (Linnaeus 1758)] populations. Mar. Ecol. 2015, 36, 1144-1154. [CrossRef]

7. Gkafas, G.A.; Tsigenopoulos, C.; Magoulas, A.; Panagiotaki, P.; Vafidis, D.; Mamuris, Z.; Exadactylos, A. Population subdivision of saddled seabream oblada melanura in the Aegean Sea revealed by genetic and morphometric analyses. Aquat. Biol. 2013, 18, 69-80. [CrossRef]

8. Gagnaire, P.; Broquet, T.; Aurelle, D.; Viard, F.; Souissi, A.; Bonhomme, F.; Arnaud-Haond, S.; Bierne, N. Using neutral, selected, and hitchhiker loci to assess connectivity of marine populations in the genomic era. Evol. Appl. 2015, 8, 769-786. [CrossRef]

9. Konstantinidis, I.; Gkafas, G.A.; Karamitros, G.; Lolas, A.; Antoniadou, C.; Vafidis, D.; Exadactylos, A. Population structure of two benthic species with different larval stages in the eastern Mediterranean Sea. J. Environ. Prot. Ecol. 2017, 18, 930-939.

10. Miller, A.D.; Versace, V.L.; Matthews, T.G.; Montgomery, S.; Bowie, K.C. Ocean currents influence the genetic structure of an intertidal mollusc in southeastern Australia-implications for predicting the movement of passive dispersers across a marine biogeographic barrier. Ecol. Evol. 2013, 3, 1248-1261. [CrossRef]

11. Macpherson, E. Ontogenetic shifts in habitat use and aggregation in juvenile sparid fishes. J. Exp. Mar. Biol. Ecol. 1998, 220, 127-150. [CrossRef]

12. Vigliola, L.; HarmelinVivien, M.L.; Biagi, F.; Galzin, R.; GarciaRubies, A.; Harmelin, J.G.; Jouvenel, J.Y.; LeDireachBoursier, L.; Macpherson, E.; Tunesi, L. Spatial and temporal patterns of settlement among sparid fishes of the genus Diplodus in the northwestern Mediterranean. Mar. Ecol. Prog. Ser. 1998, 168, 45-56. [CrossRef]

13. Bargelloni, L.; Alarcon, J.A.; Alvarez, M.C.; Penzo, E.; Magoulas, A.; Reis, C.; Patarnello, T. Discord in the family sparidae (Teleostei): Divergent phylogeographical patterns across the Atlantic-Mediterranean divide. J. Evol. Biol. 2003, 16, 1149-1158. [CrossRef] [PubMed]

14. Waples, R.S.; Gaggiotti, O. Invited review: What is a population? An empirical evaluation of some genetic methods for identifying the number of gene pools and their degree of connectivity. Mol. Ecol. 2006, 15, 1419-1439. [CrossRef] [PubMed]

15. Secor, D.H. The year-class phenomenon and the storage effect in marine fishes. J. Sea Res. 2007, 57, 91-103. [CrossRef]

16. Kerr, L.A.; Cadrin, S.X.; Secor, D.H. Simulation modelling as a tool for examining the consequences of spatial structure and connectivity on local and regional population dynamics. ICES J. Mar. Sci. 2010, 67, 1631-1639. [CrossRef]

17. González-Wanguemert, M.; Perez-Ruzafa, A.; Marcos, C.; Garcia-Charton, J.A. Genetic differentiation of Diplodus sargus (Pisces: Sparidae) populations in the south-west Mediterranean. Biol. J. Linn. Soc. 2004, 82, 249-261. [CrossRef] 
18. Planes, S.; Macpherson, E.; Biagi, F.; Garcia, R.A.; Harmelin, J.; Harmelin, V.M.; Jouvenel, J.Y.; Tunesi, L.; Vigliola, L.; Galzin, L. Spatio temporal variability in growth of juvenile sparid fishes from Mediterranean littoral zone. J. Mar. Biol. Assoc. UK 1999, 79, 137-149. [CrossRef]

19. Sambrook, J.; Fritsch, E.F.; Maniatis, T. Molecular Cloning: A Laboratory Manual, 2nd ed.; Cold Spring Harbor Laboratory Press: New York, NY, USA, 1998; Volume I.

20. Adcock, G.J.; Bernal-Ramirez, J.H.; Hauser, L.; Smith, P.; Carvalho, G.R. Screening of DNA polymorphism in samples of archived scales from New Zealand snapper. J. Fish. Biol. 2000, 56, 1283-1287. [CrossRef]

21. Brown, R.C.; Tsalavouta, M.; Terzoglou, V.; Magoulas, A.; McAndrew, B.J. Additional microsatellites for Sparus aurata and cross-species amplification within the Sparidae family. Mol. Ecol. Notes 2005, 5, 605-607. [CrossRef]

22. Toonen, R.J.; Hughes, S. Increased throughput for fragment analysis on ABI Prism 377 Automated Sequencer using a membrane comb and STR and Software. Biotechniques 2001, 31, 1320-1324. [PubMed]

23. van Oosterhout, C.; Hutchinson, W.F.; Wills, D.P.M.; Shipley, P. Microchecker: Software for identifying and correcting genotyping errors in microsatellite data. Mol. Ecol. Notes 2004, 4, 535-538. [CrossRef]

24. Raymond, M.; Rousset, F. Genepop (version 1.2) population genetics software for exact tests and ecumenicism. J. Hered. 1995, 86, 248-249. [CrossRef]

25. Weir, B.S.; Cockerham, C.C. Estimating F-statistics for the analysis of population structure. Evolution 1984, 38, 1358-1370. [PubMed]

26. Goudet, J. Fstat, A Program to Estimate and Test Gene Diversities and Fixation Indices (version 2.9.3). Available online: http://www.unil.ch/izea/softwares/Fstat.html (accessed on 15 November 2019).

27. Frichot, E.; Francois, O. Lea: An R package for landscape and ecological association studies. Methods Ecol. Evol. 2015, 6, 925-929. [CrossRef]

28. Rice, W.R. Analyzing tables of statistical tests. Evolution 1989, 43, 223-225. [CrossRef]

29. Cowen, R.K.; Paris, C.B.; Srinivasan, A. Scaling of connectivity in marine populations. Science 2006, $522-527$. [CrossRef]

30. Vafidis, D. Biogeography of the Anthozoa coelenterate fauna of the Mediterranean Sea. In Proceedings of the 9th Int Congr Zoogeography and Ecology of Greece and Adjacent Regions (ICZEGAR), Thessaloniki, Greece, 22-25 May 2002; p. 159.

31. Theocharis, A.; Georgopoulos, D.; Lascaratos, A.; Nittis, K. Water masses and circulation in the central region of the Eastern Mediterranean (E.; Ionian, S. Aegean and NW Levantine). Deep Sea Res. 1993, 40 Pt 2, 1121-1142. [CrossRef]

32. Bodur, T.; Tsigenopoulos, C.; Çagatay, T. Genetic structure of wild european sea bass (Dicentrarchus labrax L, 1758) populations in Aegean and Levantine Sea using microsatellite markers. Turk. J. Fish. Aquat. Sci. 2016, 1, 1-11.

33. Stamatis, C.; Triantafyllidis, A.; Moutou, K.A.; Mamuris, Z. Mitochondrial DNA variation in northeast Atlantic and Mediterranean populations of Norway lobster, Nephrops norvegicus. Mol. Ecol. 2004, 13, 1377-1390. [CrossRef]

34. Viret, A.; Tsaparis, D.; Tsigenopoulos, C.S.; Berrebi, P.; Sabatini, A.; Arculeo, M.; Caill-Milly, N. Absence of spatial genetic structure in common dentex (Dentex dentex Linnaeus, 1758) in the Mediterranean Sea as evidenced by nuclear and mitochondrial molecular markers. PLoS ONE 2018, 13, e0203866. [CrossRef] [PubMed]

35. Selkoe, K.A.; Watson, J.R.; White, C.; Horin, T.B.; Iacchei, M.; Mitarai, S.; Siegel, D.A.; Gaines, S.D.; Toonen, R.J Taking the chaos out of genetic patchiness: Seascape genetics reveals de La Puente-Yagueecological and oceanographic drivers of genetic patterns in three temperate reef species. Mol. Ecol. 2010, 19, 3708-3726. [CrossRef]

36. André, C.; Svedäng, H.; Knutsen, H.; Dahle, G.; Jonsson, P.; Ring, A.K.; Sköld, M.; Jorde, P.E. Population structure in Atlantic cod in the eastern North Sea-Skagerrak-Kattegat: Early life stage dispersal and adult migration. BMC Res. Notes 2016, 3, 63. [CrossRef] [PubMed]

37. Robichaud, D.; Rose, G.A. Migratory behaviour and range in Atlantic cod: Inference from a century of tagging. Fish. Fish. 2004, 5, 185-214. [CrossRef]

38. Costa, C.; Cataudella, S. Relationship between shape and trophic ecology of selected species of Sparids of the Caprolace coastal lagoon (Central Tyrrhenian sea). Environ. Biol. Fish. 2007, 78, 115. [CrossRef] 
39. Helm, B.; Ben-Shlomo, R.; Sheriff, M.J.; Hut, R.A.; Foster, R.; Barnes, B.M.; Dominoni, D. Annual rhythms that underlie phenology: Biological time-keeping meets environmental change. Proc. R. Soc. Lond. B 2013, 280, 20130016. [CrossRef] [PubMed]

40. Sbragaglia, V.; Nuñez, J.D.; Dominoni, D.; Coco, S.; Fanelli, E.; Azzurro, E.; Marini, S.; Nogueras, M.; Ponti, M.; del Rio Fernandez, J.; et al. Annual rhythms of temporal niche partitioning in the Sparidae family are correlated to different environmental variables. Sci. Rep. UK 2019, 9, 1708. [CrossRef]

41. Lipcius, R.N.; Eggleston, D.B.; Schreiber, S.J.; Seitz, R.D.; Shen, J.; Sisson, M.; Stockhausen, W.T.; Wang, H.V. Importance of metapopulation connectivity to restocking and restoration of marine species. Rev. Fish. Sci. 2008, 16, 101-110. [CrossRef]

42. Lorenzen, K.; Steneck, R.S.; Warner, R.R.; Parma, A.M.; Coleman, F.C.; Leber, K.M. The spatial dimensions of fisheries: Putting it all in place. Bull. Mar. Sci. 2010, 86, 169-177.

43. Reiss, H.; Hoarau, G.; Dickey-Collas, M.; Wolff, W.J. Genetic population structure of marine fish: Mismatch between biological and fisheries management units. Fish Fish. 2009, 10, 361-395. [CrossRef]

44. Sterner, T. Unobserved diversity, depletion and irreversibility: The importance of subpopulations for management of cod stocks. Ecol. Econ. 2007, 61, 566-574. [CrossRef]

45. Kovach, A.I.; Breton, T.S.; Berlinsky, D.L.; Maceda, L.; Wirgin, I. Fine-scale spatial and temporal genetic structure of Atlantic cod off the Atlantic coast of the USA. Mar. Ecol. Prog. Ser. 2010, 410, 177-195. [CrossRef]

46. Fu, C.; Fanning, L.P. Spatial considerations in the management of Atlantic cod off Nova Scotia, Canada. N. Am. J. Fish. Manag. 2004, 24, 775-784. [CrossRef]

(C) 2019 by the authors. Licensee MDPI, Basel, Switzerland. This article is an open access article distributed under the terms and conditions of the Creative Commons Attribution (CC BY) license (http://creativecommons.org/licenses/by/4.0/). 